\title{
8
}

\section{Sir John Crawford and Agriculture and Trade}

\author{
David Lee
}

Sir John Grenfell Crawford was one of the most significant of the seven dwarfs - the group of diminutive senior Commonwealth public servants active in the period from the 1940s to the 1960s. Agriculture and trade, the two issues with which Crawford engaged as a Commonwealth public servant, were closely connected. In 1948-49, immediately before Crawford was appointed secretary of the Department of Commerce and Agriculture, agricultural commodities still amounted to 85 per cent of Australia's exports. Moreover, wool alone made up between 40 and 50 per cent of the total in the 1940s and 1950s. Until the Second World War the domestic aspects of Australian agriculture were matters within the exclusive concern of the states, while the marketing of agricultural exports was a matter for the Commonwealth. But during the Second World War, when it acquired a monopoly of income taxes under the Uniform Taxation Act and with the aid of the defence power, the Commonwealth became much more active and interventionist on the domestic aspects of agriculture as well its trade aspects. As agricultural economist and policy-maker, Crawford's innovation was to integrate agricultural economics within public administration and policy making.

This chapter will discuss how Crawford's formative years equipped him for his leadership role in the Commonwealth Public Service and then examine how his contribution as a public servant to agricultural and trade policy qualified him to belong to the elite grouping of Australia's most powerful mandarins.

\section{The formative years}

John Crawford was born in Hurstville, Sydney, in 1910, the tenth of 12 children of Henry Crawford, a stationmaster. ${ }^{1}$ The young Crawford was forced to leave school at the age of 16 when his father left his employment in the railways, failed in an effort to set up a commercial enterprise, and was forced to labour in a quarry. Returning to school in 1927, John Crawford gained the Leaving

1 R.M. Crawford, 'My Brother Jack: Background and Early Years', in L.T. Evans and J.D.B. Miller, eds, Policy and Practice: Essays in Honour of Sir John Crawford (Canberra: Australian National University Press, 1987), 1. 
Certificate and was employed by day as a junior clerk in the New South Wales Public Service while studying at the University of Sydney for Bachelor's (1932) and Master's (1940) degrees in economics. Crawford taught in schools in Stanmore and Temora before holding a research fellowship and part-time lectureship in rural economics at the University of Sydney in the middle to late 1930s. The Depression left its mark on the young man - he was without a job for several months and sympathy for his stationmaster father having to work in a quarry left him with a 'broad sympathy with underdogs'. ${ }^{2}$

In Sydney in the 1930s Crawford was imbued with Keynesian economic ideas, a set of ideas which provided an intellectual framework for all of the dwarfs. In 1938 he wrote The National Income of Australia with Colin Clark. ${ }^{3}$ In this book Crawford and Clark suggested:

the framework of a policy which will mitigate or even overcome depression arising from the fall in export income. This is a planned expansion of public works to keep pace as far as possible with the decline in export income ... it may be desirable that Commonwealth and State Governments should deliberately plan for budget deficits. ${ }^{4}$

A reviewer in the Economic Journal described the book as combining 'skilled research with something of the excitement of a detective novel and an occasional flavour of the political pamphlet' ${ }^{5}$

Crawford's predisposition towards government intervention in rural affairs and in the broader economy was strengthened after 1938 when he won a Commonwealth Fund Fellowship to the United States. From 1938 to 1940, Crawford studied American agriculture intensively. He saw first hand the influence of active rural policies by the US Federal Government and was inspired to follow the American example by establishing a Bureau of Agricultural Economics as an agency of the Australian Government. J.D.B. Miller later commented on the importance of Crawford's American sojourn:

It was the vitality of American society which excited him; and the fact that he had gone to the United States for postgraduate work, rather than Britain, as most Australian academics then did, influenced much of his thinking about the two countries. ${ }^{6}$

After the outbreak of the Pacific War, Crawford was appointed as rural adviser to the Commonwealth Department of War Organisation of Industry and in the next

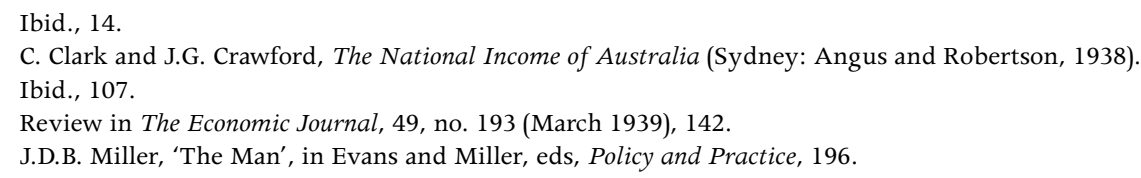


year as Director of Research in the Department of Post-War Reconstruction. In 1945 he became founding director of the Bureau of Agricultural Economics (BAE), which was transferred to the Department of Commerce and Agriculture in 1946.

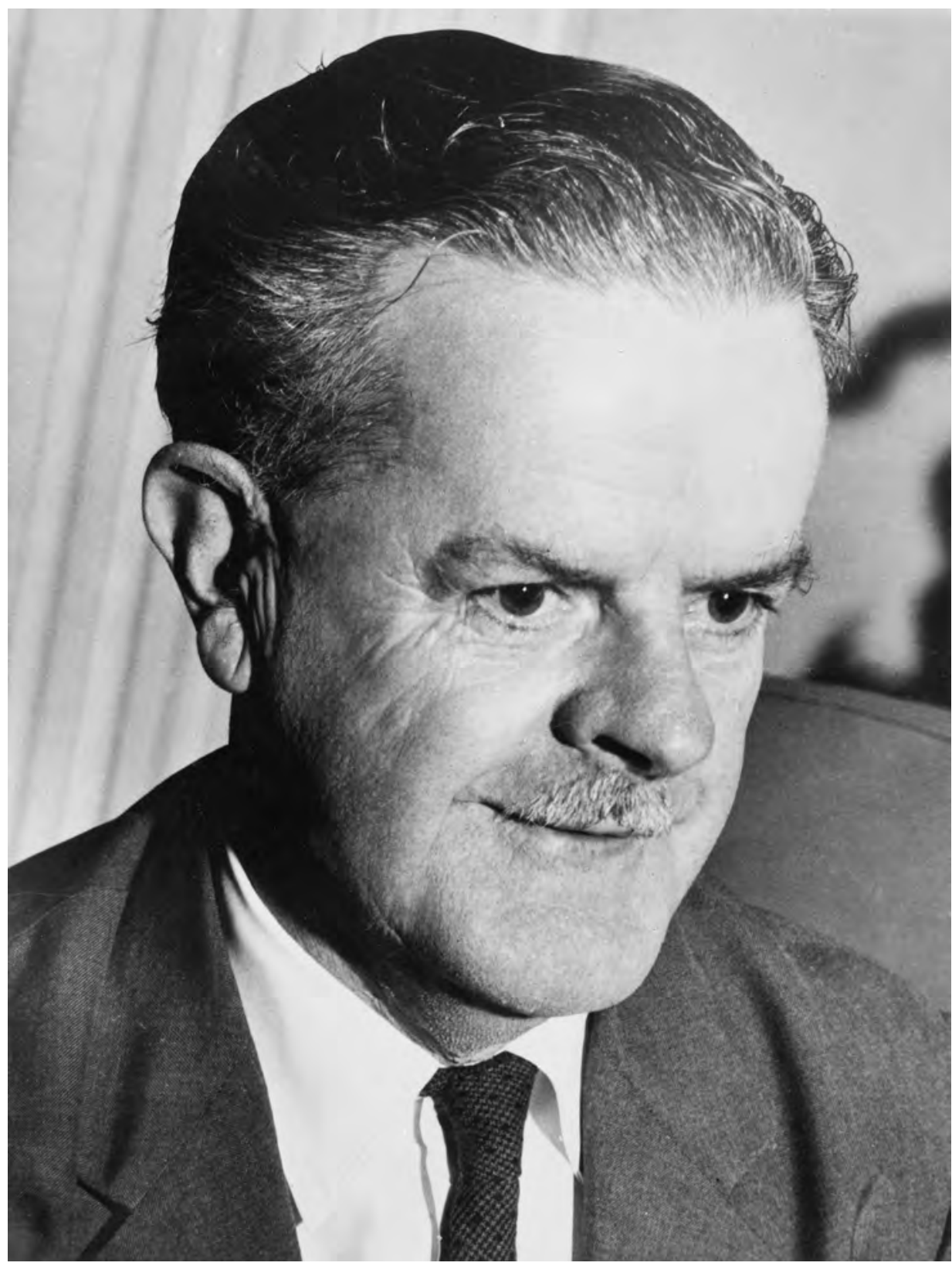

Sir John Crawford, 1967

Source: National Archives of Australia, A1200, L68147 


\section{Director of the Bureau of Agricultural Economics}

Crawford's period in Post-War Reconstruction and the BAE coincided with publication of 10 separate reports by the Rural Reconstruction Commission (RRC), a commission established by the Curtin Government in 1943. The reports dealt with soldier settlement, land tenure and environmental issues, social amenities, rural credit and commerce. Although written in the last years of the Second World War, the reports were framed against the conditions of the 1930s rather than wartime developments. ${ }^{7}$ Conveying the enthusiasm of the Hot Springs Conference of 1943 that established the Food and Agriculture Organization, they highlighted the government's obligations to raise the levels of nutrition and standards of living of its people, to improve the efficiency of agricultural production and distribution, and to foster international collaboration to achieve those ends. Crawford supported their clear assumption that government should intervene in rural affairs, particularly in marketing.

In a contemporaneous article, he had observed that the rural economy was not able, without assistance from the State, to maintain all our farmers and farm workers at a satisfactory living standard' ${ }^{8}$ Crawford was orthodox in the Second World War and early post-war years in believing in the necessity for state intervention at the domestic level. But he also urged that Australia should cooperate with other nations to create conditions internationally where states could improve the living standards of their citizens. In this sense he pursued, in a different way, what European officials such as Jean Monnet were trying to achieve (European economic collaboration to improve standards of living within European states). Later academics would describe the sorts of ideas supported by Crawford as 'embedded liberalism', namely the idea that the only way ahead for the post-war world was to construct the right blend of state, market, and democratic institutions to guarantee peace, inclusion, well-being and stability. ${ }^{9}$

Both the Chifley and Menzies governments, advised by broadly the same mandarins, subscribed to this view. The post-war Labor Government's White Paper on Full Employment had, as its main objective, the attainment of full employment for a growing Australian population with rising standards of living. These objectives required a much higher level of imports. Crawford identified increased agricultural production as a way of earning the export income to pay

\footnotetext{
7 A.W. Martin and J. Penny, 'The Rural Reconstruction Commission 1943-47', Australian Journal of Politics and History, 29 (1983), 218-36; T. Whitford and D. Boadle, 'Australia's Rural Reconstruction Commission, 1943-46: A Reassessment', Australian Journal of Politics and History, 54, no. 34 (December 2008), 525-45.

8 J.G. Crawford, 'Rural Reconstruction', Australian Journal of Science, 5 (October 1943), 37.

9 For example, J.G. Ruggie, 'International Regimes, Transactions and Change: Embedded Liberalism in the Postwar Economic Order', International Organization, 36, no. 2 (1982), 379-415.
} 
for these imports. As director of the BAE he recommended to the government ways of achieving this expansion through acceleration of land clearing and land settlement; better stock watering facilities; development of irrigation; improved pest control; more flexible credit facilities; and more orderly marketing arrangements domestically and internationally.

Crawford's framework was accepted not only by the Chifley Labor Government but also by the Country Party. In the immediate post-war period up to 1950 , despite the Chifley Government's best efforts, agricultural exports stagnated and markets for Australian exports were secured by bilateral inter-governmental contracts with the United Kingdom, which would be Australia's best customer until the late 1960s.

\section{Permanent secretary}

When the Liberal and Country parties came to office in December 1949 under the prime minister, R.G. Menzies, the deputy leader of the Country Party, John McEwen, became minister for Commerce and Agriculture. Crawford was appointed secretary in 1950, an office he held until 1956 when, after a major reorganisation, he came to McEwen's new Department of Trade. Crawford formed a constructive relationship with McEwen and with his department. In doing so, Crawford conducted himself according to the dictum of Sir Paul Hasluck that if any attempt was made by a minister 'to exercise close control over a department in such a way as to make a department the acquiescent echo of a Minister's will, the Service is being debased'. On the other hand, wrote Crawford,

the Permanent Head has the obligation of the security he enjoys to maintain his intellectual integrity and to make sure that his Minister's policy views are subjected to critical but friendly and constructive analysis. On the other hand, having done his best to persuade his Minister that a proposed line of action is wrong, a Permanent Head must carry out that policy loyally and as efficiently as possible. If he cannot do this a difficult situation can arise, one which might well lead to a change of position, preferably by agreement. ${ }^{10}$

When Crawford took up his position as secretary of the Department of Commerce and Agriculture, administrative responsibility for trade was divided between a protectionist Department of Trade and Customs and a more liberal Department of Commerce and Agriculture, which was responsible for securing

10 J.G. Crawford, 'Relations Between Civil Servants and Ministers in Policy Making', Public Administration, 19, no. 2 (June 1960), 104. 
markets abroad. ${ }^{11}$ The Korean War was sparking a worldwide boom in the prices of commodities. A particularly dramatic increase in the price of Australian wool in 1950 and 1951 sparked an import and inflationary boom, which later engendered a significant balance of payments crisis in 1952 when the price of wool and Australia's export income collapsed.

Crawford helped the Menzies Government in two respects, first by representing the Australian delegation at a (British) Commonwealth-United States wool conference in London in September 1950. At this conference he successfully resisted American pressure to abandon the auction system for wool and to purchase Australian wool at ceiling prices. He later described the issue as a policy problem 'out of the blue' and one that imposed a great strain on the department and its permanent head. As he elaborated:

The auction system for wool is almost certainly the golden calf of the Australian economy, and certainly of the wool industry. Yet there were pressing questions to be answered. They mostly boiled down to this: Was it practicable - politically, legally and economically - to suspend auctions wholly or in part, and were requests for a price ceiling practicable or justified? Who caused the price boom anyhow - the buyer or seller? In all this there was a conflict of known policies: the economic and political importance of maintaining our wool marketing system versus the desire to co-operate internationally if important allies needed our help. ${ }^{12}$

In that same year, Ronald Walker, executive member of the National Security Resources Board (NSRB), invited Crawford to advise the board on how the anticipated outbreak of a major world war might affect Australia's agricultural industries. ${ }^{13}$ Menzies had established the NSRB in December 1950 to advise the government on how to rebalance the civil and military economies. As a result of extensive examination, Crawford concluded that, in the event of war, Australia would be called on to supply additional food to India and the countries of South East Asia, whose food supply would be affected. He added that Australia would probably be asked also to fill the gap caused by reduced exports of food from Western Europe to the United Kingdom. Later in the year Crawford visited Britain and the United States to investigate the defence aspects of Australian food production. ${ }^{14}$

11 R.P. Deane, The Establishment of the Department of Trade: A Case Study in Administrative Reorganization (Canberra: Australian National University Press, 1963).

12 J.G. Crawford, 'The Role of the Permanent Head', Public Administration, 13, no. 3 (1954), 161.

13 D. Lee, 'The National Security Planning and Defence Preparations of the Menzies Government, 19501953', War \& Society, 10, no. 2 (October 1992), 123.

14 Savingram no. 28 Crawford to McEwen, 19 July 1951, National Archives of Australia (NAA) A1604/1, 5164 part 1; 'Report on Overseas Discussions - Defence Aspects of Food and Agricultural Policy by J.G. Crawford', n.d. [1951], NAA A1604.1, 51/64 part 2. 
On returning to Australia he advised the Menzies Government to urgently develop a concrete program of expanded agricultural production on the basis of complete understanding between the Commonwealth Government, leaders of primary industries and the states. On 26 April 1952, McEwen submitted a five-year plan that was hoped to add $£ A 100,000,000$ - or nearly a tenth - to Australia's income and to save $£$ A7,000,000 of imports, particularly of tobacco, cotton and linseed. ${ }^{15}$ McEwen's general aim was achieved well before 1957-58. While some of the subsequent increase in agricultural production was attributable to good seasons, the various policy measures recommended by Crawford and administered by the Department of Commerce and Agriculture stimulated enlarged investment in improved farming. Crawford wrote in 1968 that: All told the policies of 1952 did contribute to expansion without which the balance of payments situation would undoubtedly have proved even more serious than it has been on occasions in the last fifteen years.' ${ }^{\prime 6}$

In 1952, Crawford helped the government to frame a system that established a regime of import licensing which would last until 1960. One anecdote pertaining to Crawford's role in the administration of the import licensing system well illustrates his authority with ministers and his determination to protect his department. In 1957 Crawford was attending a meeting with Prime Minister Menzies, ministers and senior public servants. At this meeting Menzies attacked a deputy secretary from Trade for taking action that had previously been approved by Menzies. Crawford answered the criticism by pointing out that there had been agreement beforehand with Menzies based on a Cabinet decision that Crawford as secretary of the Department of Trade had opposed and then accepted after it had been made. Crawford told Menzies that he was 'fed up' with attacks on his officers for implementing decisions made by ministers. He was prepared to resign and make public his reasons unless the prime minister apologised to the deputy. Menzies did apologise and this ended Menzies' attacks on Crawford's department and its head in that area of policy. ${ }^{17}$

\section{The shift from bilateralism to multilateralism}

Crawford's greatest achievement as a senior official in Commerce and Agriculture and, then, Trade was to help both Labor and Liberal-Country party governments manage the transition from a bilateral to a multilateral framework in Australian trade policy. It is first necessary to sketch the historical background in order to put this achievement in context.

15 'Australia Sets the Sights', The Economist, 26 April 1952, cited in J.G. Crawford, ed., Australian Trade Policy: 1942-1966 (Canberra: Australian National University Press, 1968), 450.

16 Crawford, ed., Australian Trade Policy, 438.

17 D.B. Williams, 'Contributions to Agricultural Economics', in Evans and Miller, eds, Policy and Practice, 18. 
In reaction to the Depression, Australia in 1932 had signed a trade agreement with the United Kingdom at Ottawa. The Ottawa Agreement was based on the exchange of tariff preferences between Empire (later Commonwealth) countries. The Depression years also saw the emergence of a currency area, the sterling area, to which Australia belonged. Members of the sterling area conducted their trade in sterling, pegged their currencies to the pound, maintained sterling reserves in London and collectively rationed their use of hard currencies such as the US dollar.

When, in 1942, both Britain and Australia signed the Mutual Aid Agreement with the United States (in return for Lend-Lease aid), they both agreed to participate in long-term arrangements under Article VII of the agreement for the reduction of barriers to world trade. Crawford later wrote that '[a]ll major developments in Australian post-war trade policy, at least up to the late 1950s, can be traced back to the commitment in Article VII'. ${ }^{18}$

The Article VII commitments led in due course to the establishment of the General Agreement of Tariffs and Trade (GATT) as a provisional instrument to provide rules for international trade based on the principle of nondiscrimination. The GATT was immediately successful in framing rules for, and helping reduce, tariffs on manufactured goods. But agriculture was largely exempted from its rules and, in the early 1950s, this situation was exacerbated when the United States received a waiver from what disciplines there were on agriculture. Doubly irksome for Australia as an agricultural exporting country was the GATT's decision to limit Australia's benefits from imperial preference by a 'no-new preference' rule. $^{19}$

In 1953, the prime minister (Menzies) announced that Australia would be seeking major changes in the GATT to secure flexibility to make changes to the tariff; to gain some relaxation of the GATT's no-new preference rule; and to remedy the imbalance in the GATT by addressing such issues as protection of agricultural subsidies, surplus disposal and state trading. Crawford was successful in gaining some flexibility for the operation of Australia's tariff system with its independent Tariff Board; was unsuccessful in modifying the no-new preference rule; but made some progress in improving the effectiveness of the GATT. ${ }^{20}$

18 Crawford, Australian Trade Policy, 8. Crawford modified the statement by acknowledging that 'Australia's propensity for fairly high tariffs for some industries [was] not altogether consistent with the spirit of Article VII, although it [was] quite within the framework of tariff-making machinery allowed by GATT'.

19 Under the General Agreement of Tariffs and Trade's (GATT) rules no new preferences could be extended where none existed before and existing preferences could not be widened beyond their October 1946 absolute level.

20 S. Harris, 'Managing Australia's Shift to Multilateralism', in Evans and Miller, eds, Policy and Practice, 58-61. 
Indeed, Crawford was the driving force in persuading the GATT to adopt a more specific approach against subsidies insofar as his general criticism of agricultural protection culminated in the 1957 Haberler Report. The Haberler Committee was appointed as a result of an Australian initiative in the GATT to review agricultural protectionism as it affected exporters of primary products. This report vindicated what Crawford and others had been saying about agricultural protection by noting how domestic attempts to create price stability created a greater degree of price instability in international markets. ${ }^{21}$

Crawford helped to persuade the Menzies Government to remain supportive of the GATT despite its imperfection and its imbalance as far as Australia's trade interests were concerned. Previously, in 1952, the Menzies Government had debated whether Australia should be looking for some more tightly integrated British Commonwealth economic bloc or moving towards more rapid convertibility of sterling with the US dollar. Crawford advised the government that autarky was impossible for the (British) Commonwealth. Many of the Commonwealth's members, including Australia, were dependent on nonCommonwealth markets for important exports, in Australia's case for wool, wheat and minerals. Crawford later wrote,

[the] 1952 conference really turned its back on the hopes of some (including those held by the Australian Prime Minister) that the Ottawa road would be further explored, turning the Commonwealth into a more tightly integrated economic unit. The debate was not difficult nor was it prolonged, but it was decisive ... simply because the case against was overwhelming. ${ }^{22}$

This advice influenced his attitude to the 1956 review of the Ottawa Agreement. The Commonwealth Prime Ministers' Conference of 1952 had made it clear that adding to the mutual preference structure was not an acceptable option for the Commonwealth as a whole. Moreover, the 1955 GATT Review had decisively rejected Australia's attempt to gain even minor latitude in its enjoyment of preferences. The Menzies Government and its advisers therefore looked at all options in expanding its overseas trade, including the Ottawa Agreement.

Crawford had formed the view by that time that the agreement was imbalanced in Britain's favour. British exports to Australia were expanding much faster than Australian exports to the United Kingdom. Put another way, the market in the United Kingdom for Australian goods was a declining one. ${ }^{23}$ Accordingly, on 24 May 1956, Menzies announced that trade discussions would take place with

21 Crawford, Australian Trade Policy, 133-4.

22 Ibid., 101.

23 Ibid., 321. 
British ministers to review the Ottawa Agreement. ${ }^{24}$ Crawford and McEwen adopted a clear-eyed bargaining position to these negotiations by being willing to have no agreement at all rather than one in which Britain accepted little or no revision to an agreement deemed to be out of balance. The result was an agreement under which Britain used its best endeavours to maintain imports of Australian wheat and flour to no less than 28 million bushels a year and to reduce the preferential margins granted to British imports. ${ }^{25}$ The latter concession was significant in forming part of Crawford's plan to gain negotiating coin in trade negotiations with Japan. Crawford emphasised the symbolic importance of the renegotiation of Ottawa as a signal of Australia's retreat from Empire in the postwar period.

Crawford had always been prescient about Australia's long-term trading interests - in foreseeing the opportunity for Asia to compensate for limited markets in Europe. This was exemplified in a chapter he wrote in a book published in 1938 in which he called for 'economic appeasement' of Japan. ${ }^{26}$ The article was written at a time when orthodox opinion was that Australian security would be secured by cooperating with Britain in the Singapore strategy and when Australia was just recovering from a disastrous attempt to shift purchases of imported textiles away from Japan towards the United Kingdom. In the 1938 article, Crawford argued that Australia stood to gain from Japan's peaceful economic expansion and that Japan was already becoming as a trading partner for Australia, what Japan, China and the rest of East Asia might in the future collectively become. The young economist argued for a system of 'collective agreements' to take the place of 'power politics'. By collective agreements he envisaged an acknowledgement of trading rights and freedoms within accepted rules. ${ }^{27}$

In the 1950s, Crawford followed on his earlier thoughts by pressing for a trade agreement with Japan at a time when powerful interest groups in the community and within the bureaucracy were opposed to such a course. Under Article 12 of the Peace Treaty signed by Japan in 1952, Japan was obliged to accord Allied Nations, including Australia, most-favoured-nation status with respect to trade. What would happen in four years time touched a real difficulty for Australia which not only did not accord Japan most-favoured-nation treatment with regard to the tariff but, in addition, extensively discriminated against Japan in its licensing of imports.

\footnotetext{
24 Press statement by R.G. Menzies, 24 May 1956; Crawford, Australian Trade Policy, 336-7.

25 Harris, 'Managing Australia's Shift to Multilateralism', 55-8.

26 J.G. Crawford, 'Australia as a Pacific Power', in W.G.K. Duncan, ed., Australia's Foreign Policy (Sydney: Angus and Robertson, 1938), 69-121.

27 P. Drysdale, 'The Relationship with Japan: Despite the Vicissitudes', in Evans and Miller, eds, Policy and Practice, 66-71.
} 
Crawford was concerned by an outcome after 1956 in which Japan retaliated, as it had during the Trade Diversion dispute of the 1930s, by restricting access of Australian primary products to the Japanese market. At the same time, Crawford well appreciated that the objective of reaching a trade agreement with Japan was affected by powerful currents in Australia, including the bitter legacy of the Pacific War and the concern by Australian manufacturers at having to compete against cheap Japanese imports. As a Sydney Morning Herald leading article commented on 17 August 1955, 'Japanese trade is associated in the minds of Australians with cheap labour, price undercutting, shoddy goods and "dumping", just as Japanese "defence policy" still tends to be envisaged in terms of brutal militarism' ${ }^{28}$

Crawford discounted the idea that Australia could continue to enjoy the advantages of an expanding market in Japan while denying benefits to the Japanese in the Australian market. For one thing, the United States was able to sell Japan wheat from production and surplus stocks; for another, Crawford feared that Japan might give strong preference to synthetics over purchasing wool from Australia. ${ }^{29}$ In June 1953, Crawford participated in a meeting of the permanent heads of Commerce and Agriculture, Trade and Customs, External Affairs and the Treasury to prepare a document for the Cabinet Committee on Overseas Commercial Relations being held on 23 June, a document that would be submitted to full Cabinet on 2 July.

Crawford regarded the statement emerging from the heads of department meeting, which urged an easing of the highly restrictive import licensing of Japanese goods, as the 'important document' in the process leading up to trade talks with Japan. ${ }^{30}$ The recommended course of action led to a significant increase in Japan's access to the Australian trade market but not towards trade talks with Japan on the basis of non-discriminatory treatment. This was because of the reservation of Frank Meere, comptroller-general of Customs, who argued that further liberalisation was 'impracticable at this stage'; Meere was an ardent advocate of tariff protection. ${ }^{31}$

Cabinet did not respond to a further request for trade talks with Japan made strongly by McEwen and Crawford in January 1954 (elections were scheduled for May 1954). By November of that year, however, Cabinet had agreed to

\footnotetext{
28 Sydney Morning Herald, 17 August 1955.

29 Crawford, Australian Trade Policy, 352-3.

30 Drysdale, 'The Relationship with Japan', 75; 'Note for Ministers agreed by Departments of Commerce \& Agriculture, External Affairs, Trade \& Customs and Treasury', 23 June 1953, in Wendy Way, ed., The Australia-Japan Agreement on Commerce 1957 (Canberra: Australian Government Publishing Service, 1997), 54-8.

31 Drysdale, 'The Relationship with Japan', 75.
} 
proceed to trade talks with Japan. In October 1955, Crawford wrote to Meere with an outline of what he hoped could be achieved in trade negotiations with Japan and commenting:

I believe that there is some importance in our being amongst the first to initiate talks with the Japanese and also being able to say at G.A.T.T. that we are, in fact, both willing and currently undertaking talks with the Japanese, and I wonder if you could give me a call when you have a chance to look at this. ${ }^{32}$

Crawford hoped that Australia would be able to negotiate fair and reasonable access to the Japanese market in the form of most-favoured-nation treatment on the tariff and non-discriminatory treatment in regard to import licensing.

Crawford's campaign to conclude a trade agreement with Japan was greatly assisted when the Department of Trade and Customs and the Department of Commerce and Agriculture merged in 1956 into a single Department of Trade with Crawford as secretary; customs administration was assigned to a Department of Customs and Excise and the Department of Primary Industry was created at the same time. On 25 October 1956, the acting Trade minister, William McMahon, announced that trade negotiations between Australia and Japan would commence. A year later, a satisfactory outcome was reached. It encompassed non-discriminatory access to Australian markets for Japanese exports; guaranteed access to Japanese markets for Australian primary products and assured safeguards for Australian industry.

The Australia-Japan Agreement on Commerce was a landmark agreement under which, within a decade, Japan would overtake Britain as Australia's major trading partner. The agreement, however, was concluded in the face of hostility from sectional interests who subjected Crawford personally to what he has described as the worst personal attack he experienced during his public career'. ${ }^{33}$

\section{Conclusion}

In 1960 Crawford left the public service to become in due course vice-chancellor and chancellor of The Australian National University. He built a career as an academic and university administrator which was as successful and influential as his career as a mandarin from 1945 to 1960. J.D.B. Miller has described his essential character in both his bureaucratic and academic careers:

32 Crawford to Meere, 14 October 1955, Crawford Papers, National Library of Australia, MS 4514/9/33.

33 Drysdale, 'The Relationship with Japan', 77. 
He endeared himself to those with whom he worked because he seemed moderate in opinion though extreme in concentration; because he was essentially fair-minded in his approach to problems; because he liked to help lame dogs over stiles; and because, when roused, he could speak boldly and with much effect. ${ }^{34}$

As public servant and mandarin, his loyal and dispassionate approach to serving government had made him equally valued by both Labor and Liberal-Country party governments, and the ministers he admired most, J.B. Chifley and John McEwen, came from both sides of politics. While he continually searched for agreed principles in politics, his success as a public servant also came from his recognition that politics was the art of the possible. 'He was', as Miller put it,

A natural politician who knew, almost by instinct, what would work and what would not, whether it was a ploy at meeting, a resolution which required acceptance, or an overall policy which had to satisfy various groups which normally would not agree with one another. ${ }^{35}$ 
This text is taken from The Seven Dwarfs and the Age of the Mandarins: Australian Government Administration in the Post-War Reconstruction Era, edited by Samuel Furphy, published 2015 by ANU Press, The Australian National University, Canberra, Australia. 